\title{
The Establishment of Green Construction Evaluation of Building Projects Based on Cloud Model
}

\author{
Lin Shizhu ${ }^{\mathrm{a}}$ and Zhang $\mathrm{Yao}^{\mathrm{b}}$ \\ Baotou 014010, Inner Mongolia, China. \\ alinshizhusy@aliyun.com, btnkdzy@163.com
}

Keywords: Green Constriction; Cloud Model; Entropy Method; Index System; Evaluation;

\begin{abstract}
Based on extensive investigation, aiming the randomness and fuzziness characteristics existing in the evaluation, considering comprehensively index 5 aspects including the construction technology management, the environmental load of construction process, energy consumption, resource utilization and economy index, constructing 3 levels of evaluation system, the green construction evaluation system model is based on the entropy weight and cloud model. And the results of actual engineering cases are used to compared with the results of fuzzy comprehensive evaluation method to verify its practicability and reliability. It provides a new tool for the green construction evaluation and a scientific basis for evaluation of sustainable development of our country construction industry.
\end{abstract}

\section{Introduction}

Green construction evaluation is a multilevel and multi-index comprehensive evaluation system , and it is affected by multiple factors ${ }^{[1,2]}$. Currently, the research on the evaluation of green construction field in our country are mainly concentrated in the traditional model of evaluation, such as fuzzy comprehensive evaluation, BP neural network, grey clustering evaluation and other methods $[2,3]$. But these evaluation methods cannot solve the effective combination problems of fuzziness and randomness.

This paper establishes evaluation index by reviewing of literature and expert questionnaire and the cloud model is introduced into the field of green construction evaluation to better describe the fuzziness, randomness and its correlation and achieve the conversion between qualitative concept and quantitative representation. It provides a new method for the index evaluation of qualitative and quantitative.

\section{The Theory of Cloud Model}

Cloud model is first proposed in 1995 by Professor Li Deyi ${ }^{[4]}$, the Chinese Academy of Engineering, which based on probability and fuzzy mathematics theory,combining the characteristics of data distribution, using the expected value(Ex),entropy(En) and hyper entropy $(\mathrm{He})$ to describe an uncertain concept.

\section{Definition of Cloud}

Definition $1^{[5]}$ If $U$ is a quantitative domain of numeric representation, $C$ is a qualitative concept on the $\mathrm{U}$ and qualitative number of $\mathrm{x} \in \mathrm{U}$ is a random realization of qualitative concept of $\mathrm{C}$, then $\mathrm{x}$ is a random number with a stable tendency, which $x$ on certainty $C$ of $\mu(x) \epsilon[0,1]$. That is to say if $\mu: U \rightarrow[0,1], \forall x \in U$ and $x \rightarrow \mu(x)$, then it is called cloud in the domain $U$ and denoted as $C(X)$.Each $\mathrm{x}$ as a cloud dropt.

\section{Cloud Generator}

1.Forward Cloud Generator(FCG) is a process to produce quantitative values by digital characteristics of C (Ex, En, He) (Figure 1).

2.Backward Cloud Generator(BCG) is the converter of uncertainty between quantitative value and its qualitative linguistic value and is a mapping from quantitative to qualitative.(Figure 1). 


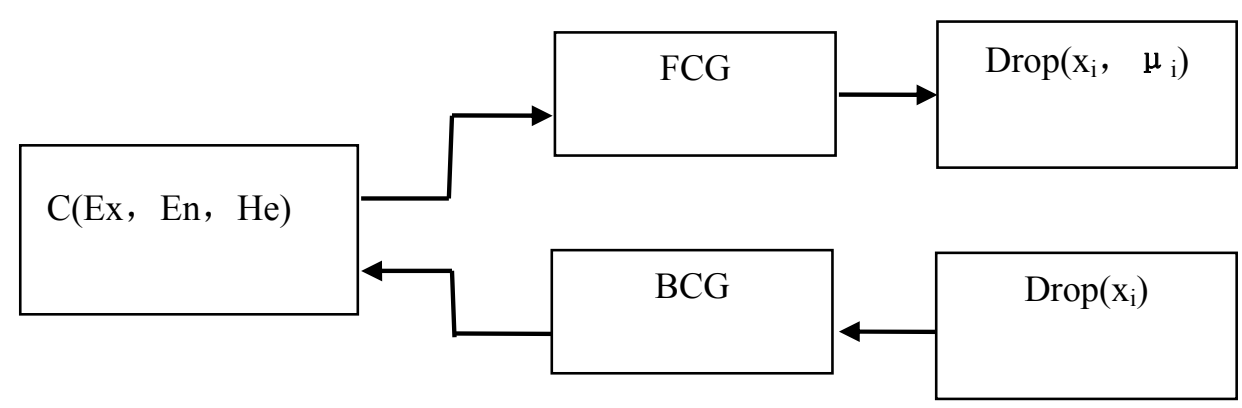

Fig.1 The schematic diagram of FCG and BCG

\section{Comprehensive Evaluation Based on Cloud Model}

\section{The Establishment of The Evaluation System}

This thesis summarized the green construction evaluation index system based on the existing technical specifications and standards, laws and regulations and domestic and overseas relavent research. Following the principles of availability, effectiveness, comprehensiveness and operability, using the methods of literature review and expert questionnaire to establish the evaluation index system and determine the evaluation standard which consider comprehensively various factors(Table 1). 
Tab.1 Evaluation indicator system of green construction and the standard reference

\begin{tabular}{|c|c|c|c|c|c|c|c|}
\hline \multicolumn{3}{|c|}{ Indexes } & \multicolumn{5}{|c|}{ Evaluation Criterion } \\
\hline $\begin{array}{c}\text { Classific } \\
\text { on }\end{array}$ & $\begin{array}{c}\text { Cod- } \\
\text { ing }\end{array}$ & Index & Consideration & $\begin{array}{l}\text { Excellent } \\
(3-4)\end{array}$ & $\begin{array}{c}\text { Good } \\
(2-3)\end{array}$ & $\begin{array}{c}\text { Qualified } \\
(1-2)\end{array}$ & $\begin{array}{l}\text { Unqualified } \\
(0-1)\end{array}$ \\
\hline \multirow{7}{*}{$\begin{array}{l}\text { Construction } \\
\text { Technology } \\
\text { Managemen } \\
\text { t(M) }\end{array}$} & M1 & $\begin{array}{l}\text { Management } \\
\text { participation }\end{array}$ & Full participation & $\begin{array}{l}\text { Strategy of } \\
\text { top managers }\end{array}$ & $\begin{array}{l}\text { Middle-level } \\
\text { managers }\end{array}$ & $\begin{array}{l}\text { First-line } \\
\text { managers }\end{array}$ & $\begin{array}{l}\text { Nonparticip } \\
\text {-ator }\end{array}$ \\
\hline & M2 & Staff training & Total training time & $>40 \mathrm{~h}$ & $>30 \mathrm{~h}$ & $>20 \mathrm{~h}$ & $<20 \mathrm{~h}$ \\
\hline & M3 & Staffing and Security & $\begin{array}{l}\text { Personnel quality(the proportion } \\
\text { of university diploma) }\end{array}$ & $>20 \%$ & $>15 \%$ & $>10 \%$ & $<10 \%$ \\
\hline & M4 & $\begin{array}{l}\text { reen const } \\
\text { chnology }\end{array}$ & \multicolumn{5}{|c|}{$\begin{array}{l}\text { Compiling the green construction scheme and approvaling it in accordance with } \\
\text { relevant provisions;Green construction scheme shall include environmental protection } \\
\text { measures, material saving, water saving, energy saving and land saving measures. }\end{array}$} \\
\hline & M5 & gement & \multicolumn{5}{|c|}{$\begin{array}{l}\text { The construction layout is compact;Saving construction site area; Giving priority to } \\
\text { utilize idel land. }\end{array}$} \\
\hline & M6 & $\begin{array}{l}\text { nmental } \\
\text { ement }\end{array}$ & $\begin{array}{l}\text { The contractor passes the } \\
\text { ISO14000 certification. }\end{array}$ & Yes & -- & -- & No \\
\hline & M7 & evaluation & Population evaluation & Very satisfied & Satisfied & Qualified & Unqualified \\
\hline \multirow{6}{*}{$\begin{array}{l}\text { Environmen } \\
\text {-tal load of } \\
\text { construction } \\
\text { process } \\
\text { L }\end{array}$} & L1 & $\begin{array}{l}\text { Ecological environm } \\
\text { ental impact }\end{array}$ & \multicolumn{5}{|c|}{$\begin{array}{l}\text { Excavation is reasonable;Maintaining balance between cutting and filling;Storing } \\
\text { dangerous and chemicals goods have strict water-resisting layer;Preventing soil } \\
\text { pollution. }\end{array}$} \\
\hline & L2 & $\begin{array}{l}\text { spheric } \\
\text { ion }\end{array}$ & \multicolumn{5}{|c|}{$\begin{array}{l}\text { The exhaust emissions of construction vehicles,machineries and equipments } \\
\text { should meet national and local standards;Taking effective measures to reduce the } \\
\text { harmful components in the tail gas;Taking measures to suppress dust; Cement and } \\
\text { other building materials which which easy to produce dust should be sealed storage. }\end{array}$} \\
\hline & L3 & Water pollution & \multicolumn{5}{|c|}{$\begin{array}{l}\text { Sewage discharge should meet the comprehensive standard;Take measures to avoid } \\
\text { the rain contact with other engineering of sewage; Project sewage is treated by the } \\
\text { sedimentation and drained into the municipal sewage pipe. }\end{array}$} \\
\hline & L4 & Noise pollution & $\begin{array}{l}\text { The noise is lower than the } \\
\text { noise limit standard }\end{array}$ & $>5 \mathrm{~dB}$ & $>3 \mathrm{~dB}$ & $\begin{array}{l}\text { Reached } \\
\text { standard }\end{array}$ & \begin{tabular}{|l|} 
Below \\
Standard
\end{tabular} \\
\hline & L5 & Light pollution & \multicolumn{5}{|c|}{$\begin{array}{l}\text { Is there any design measures to control light pollution;Taking shielding measures to } \\
\text { reduce the impact on the surrounding residents. }\end{array}$} \\
\hline & L6 & ction & $\begin{array}{l}\text { The amount of construction } \\
\text { garbage per million square meters }\end{array}$ & $<300 \mathrm{t}$ & $<350 \mathrm{t}$ & $<400 \mathrm{t}$ & $>400 \mathrm{t}$ \\
\hline \multirow[t]{2}{*}{$\begin{array}{l}\text { Energy } \\
\text { consumption } \\
\text { S }\end{array}$} & S1 & nergy consumption & \multicolumn{5}{|c|}{$\begin{array}{l}\text { The Consumption of natural and mineral resources in the production process of } \\
\text { building materials per unit area;Construction process try to use clean energy and } \\
\text { have renewable energy utilization facilities. }\end{array}$} \\
\hline & S2 & Eners & Savings compared with the quotas & \begin{tabular}{|l|}
$>2 \%$ \\
\end{tabular} & $>1.5 \%$ & $>1 \%$ & $<1 \%$ \\
\hline \multirow{3}{*}{$\begin{array}{l}\text { Resource } \\
\text { utilization } \\
\text { R }\end{array}$} & R1 & Material utilization & $\begin{array}{l}\text { Savings that actual consumption } \\
\text { than calculated consumption }\end{array}$ & $>3 \%$ & $>2 \%$ & $>1 \%$ & $<1 \%$ \\
\hline & $\mathrm{R} 2$ & Capacity utilization & \multicolumn{5}{|c|}{$\begin{array}{l}\text { The use rate of equipment which is advanced high efficiency and no pollution or less } \\
\text { pollution. }\end{array}$} \\
\hline & R3 & \begin{tabular}{ll|} 
Water & resources \\
utilization
\end{tabular} & $\begin{array}{l}\text { Savings that actual consumption } \\
\text { than calculated consumption }\end{array}$ & $>15 \%$ & $>10 \%$ & $>5 \%$ & $<5 \%$ \\
\hline $\begin{array}{l}\text { Economic } \\
\text { index }\end{array}$ & E1 & $\begin{array}{l}\text { Investment in } \\
\text { environment }\end{array}$ & \multicolumn{5}{|c|}{ Is there any necessary funds for the environmental protection to be invested. } \\
\hline & $\mathrm{E} 2$ & $\begin{array}{l}\text { Cost of pollution } \\
\text { treatment }\end{array}$ & \multicolumn{5}{|c|}{$\begin{array}{l}\text { The cost of environmental pollution treatment which is caused by the construction } \\
\text { process. }\end{array}$} \\
\hline
\end{tabular}

\section{The Determining Method of Weights Based on Entropy Weight}

At present, the weight of green construction indicators is usually determined by subjective method. This will cause the deviation of evaluation results by the subjective factors. In information theory, entropy $H(x)=-\sum p(x i) \ln p(x i)$ can reflect the disorder degree of system. So according to the degree of variation of each index, entropy information provide the basis method to calculate weight of each index for the multi-index comprehensive evaluation. Proceed as follows:

Step 1: Constructing matrix $\mathrm{R}$ that has $\mathrm{n}$ evaluation object and $\mathrm{m}$ evaluation indexes:

$$
R=\left(r_{i j}\right)_{m * n}^{*} \quad(i=1,2, \cdots, m ; j=1,2, \cdots, n)
$$

Step 2: Standardizing the judgment matrix of $\mathrm{R}$ :

$$
X_{i \mathrm{j}}=x_{\mathrm{ij}}-\mathrm{r}_{\min } / r_{\max }-r_{\min }\left(\mathrm{r}_{\max }, \mathrm{r}_{\min } \text { is maximum and minimum values in different objects }\right)
$$

Step 3:Calculating the proportion of $f_{\mathrm{ij}}$ for samples. Partial data are normalized so that the $\log$ has no meaning on the entropy for weights. The date has to be processed. Therefore, amend $\mathrm{f}_{\mathrm{ij}}$ :

$$
\mathrm{f}_{\mathrm{ij}}=1+x_{i j} / \sum_{i=1}^{\mathrm{n}}\left(1+x_{i j}\right)
$$


Step 4: Calculating the entropy of $\mathrm{e}_{\mathrm{j}}$ :

$e_{j}=-k \sum_{i=1}^{n} f_{i j} \ln f_{i j}(\mathrm{k}$ is connected with $\mathrm{n}$ of samples, this paper take $\mathrm{k}=1 / \ln \mathrm{n})$

Step 5:According to the definition of entropy, using the value of $\mathrm{n}$ evaluation objects and $\mathrm{m}$ evaluation indexes to determine the entropy of evaluation index:

$$
\omega_{\mathrm{j}}={ }^{1-e_{j}} m-\sum_{j=1}^{m} e_{j}
$$

\section{Comprehensive Evaluation Model Based on Entropy and Cloud Model}

Because green construction evaluation is fuzzy and random, green construction comprehensive evaluation theory and model which is set up by the concept and method of cloud model is more practical than the traditional evaluation methods. In this paper, the theory of cloud model and entropy method is used for constructing a new model of comprehensive evaluation of green construction. The comprehensive evaluation model is established and proceed as follows:

Step 1: Establishing factors domain on the evaluation object $U=\left\{u_{1}, u_{2}, \cdots, u_{n}\right\}$;

Step 2: Establishing remark domain $\mathrm{V}=\left\{\mathrm{v}_{1}, \mathrm{v}_{2}, \ldots \ldots, \mathrm{v}_{\mathrm{m}}\right\}$;

Step 3: Using the entropy method to calculate the weight of index $\omega=\left\{\omega_{1}, \omega_{2}, \cdots, \omega_{n}\right\}$;

Step 4: Proceeding single factor evaluation between factors domain $U$ and remark domain $V$ and setting up fuzzy relation matrix $\mathrm{R}$. In $\mathrm{R}, \mathrm{r}_{\mathrm{ij}}$ represents the degree of membership that $u_{i}$ corresponds to $\mathrm{v}_{\mathrm{j}}$.If $\mathrm{x}_{\max }, \mathrm{x}_{\min }$ is the upper and lower bounds value that factor $\mathrm{i}(\mathrm{i}=1,2, \ldots \mathrm{n})$ corresponds to rating $\mathrm{j}(\mathrm{j}=1,2, \ldots \mathrm{m})$, then this qualitative concept can be expressed by normal cloud model which factor $\mathrm{i}$ corresponds to the rating $\mathrm{j}$.

$$
E \mathrm{x}_{\mathrm{ij}}=\left(x_{\text {min }}+x_{\text {max }}\right) / 2 \quad v_{\text {min }} \leq x_{\text {min }}<x_{\text {max }} \leq v_{\text {max }}
$$

Among them, $v_{\min }$ and $v_{\max }$ respectively represent lower and upper limit of remark domain.

The boundary value is a transition value from one rating to another and is center fuzzy boundary, which belongs to corresponding two ratings that is equal in the membership.That is to say:

$$
\begin{array}{ll}
E \mathrm{n}_{i j}=x_{\max }-x_{\min } / 2.355 & v_{\min }<x_{\min }<x_{\max }<v_{\max } \\
E \mathrm{n}_{i j}=x_{\max }-x_{\min } / 1.177 & x_{\min }=v_{\min } \text { 或 } x_{\max }=v_{\max }
\end{array}
$$

Hyper entropy is adopted as uncertainty measure of entropy and can reflect the cohesion of cloud droplets. It can select by experience and experiment. The smaller hyper entropy is, the smaller thickness of the cloud is. Vice versa. In this paper,according to the experience to select $\mathrm{He}_{\mathrm{ij}}$.

Step 5: According to the various indicators value of evaluation project, using the FCG to determine the membership matrix $\mathrm{R}=\left(\mathrm{r}_{\mathrm{ij}}\right)_{\mathrm{n} * \mathrm{~m}}$. Because acquisition of membership matrix by the cloud model is different from traditional fuzzy mathematics and $r_{i j}$ is not a fixed value, it is necessary to repeat the cloud generator $\mathrm{N}$ times for improving the credibility of the evaluation and calculate the average value.

$$
\mathrm{r}_{\mathrm{ij}}=\sum_{k=1}^{N} r_{i j}{ }^{k} / N \text {. }
$$

Step 6: Fuzzy subsets $\mathrm{G}$ of the comprehensive evaluation of green construction is obtained by fuzzy conversion between the vector $\omega$ and membership matrix $Z, G=\omega \cdot R=\left(g_{1}, g_{2}, \cdots, g_{m}\right)$. Finally, according to maximum membership principle,selecting the rank which corresponding biggest membership degree as the comprehensive evaluation results .

\section{Case Calculation}

Based on table 1, using expert questionnaire to obtain the raw data of four samples of green construction project and construct the green constructing evaluation cloud model.Index 
values are as follows (Table 2).

Tab.2 Indicator table of green construction in environmental

\begin{tabular}{|c|c|c|c|c|c|c|}
\hline Classification & Coding & Consideration & $\mathrm{P} 1$ & $\mathrm{P} 2$ & P3 & $\mathrm{P} 4$ \\
\hline & M1 & Management participation & 2.0 & 3.2 & 3.8 & 2.9 \\
\hline Construction & M2 & Employee training & 2.1 & 2.9 & 2.7 & 3.3 \\
\hline Technology & M3 & Staffing and Security & 2.4 & 2.8 & 3.5 & 2.8 \\
\hline Management & M4 & Green construction technology & 1.9 & 3.4 & 3.1 & 3.5 \\
\hline M & M5 & Construction management & 2.1 & 2.9 & 3.0 & 2.8 \\
\hline & M6 & Environmental Management & 2.7 & 2.8 & 3.0 & 1.8 \\
\hline & M7 & Social evaluation & 2.0 & 1.7 & 2.8 & 2.0 \\
\hline Environmental & $\mathrm{L} 1$ & Ecological environmental impact & 1.3 & 1.7 & 2.6 & 2.8 \\
\hline load of & $\mathrm{L} 2$ & Atmospheric pollution & 2.2 & 2.8 & 2.3 & 2.6 \\
\hline construction & L3 & Water pollution & 1.8 & 1.9 & 3.3 & 1.8 \\
\hline process & L4 & Noise pollution & 2.1 & 2.4 & 3.0 & 2.5 \\
\hline $\mathrm{L}$ & L5 & Light pollution & 2.6 & 3.2 & 3.1 & 3.3 \\
\hline & L6 & Construction garbage & 1.8 & 2.8 & 3.3 & 1.9 \\
\hline Energy & $\mathrm{S} 1$ & Energy consumption & 1.4 & 2.8 & 2.9 & 2.3 \\
\hline consumption $\mathrm{S}$ & $\mathrm{S} 2$ & Energy conservation & 1.3 & 2.6 & 3.3 & 2.1 \\
\hline Resource & $\mathrm{R} 1$ & Material utilization & 1.5 & 2.2 & 3.0 & 2.7 \\
\hline utilization & $\mathrm{R} 2$ & Capacity utilization & 2.1 & 2.3 & 3.1 & 1.7 \\
\hline $\mathrm{R}$ & $\mathrm{R} 3$ & Water resources utilization & 1.8 & 1.3 & 3.2 & 3.0 \\
\hline Economic & E1 & Investment in environmental protection & 1.7 & 2.9 & 3.2 & 1.9 \\
\hline Indicator & E2 & Cost of pollution treatment & 1.5 & 3.0 & 2.7 & 3.1 \\
\hline
\end{tabular}

According to the established green construction evaluation index system and evaluation standard, corresponding normal cloud model is expressed as the following form by formula (6) - (8):Excellent IV (4,0.8496,0.01), Good III (2.5,0.4246,0.01), Qualified II $(1.5,0.4246,0.01)$, Unqualified I $(0,0.8496,0.01)$. And structuring the normal cloud model by (Ex, En, He) (Figure 2).

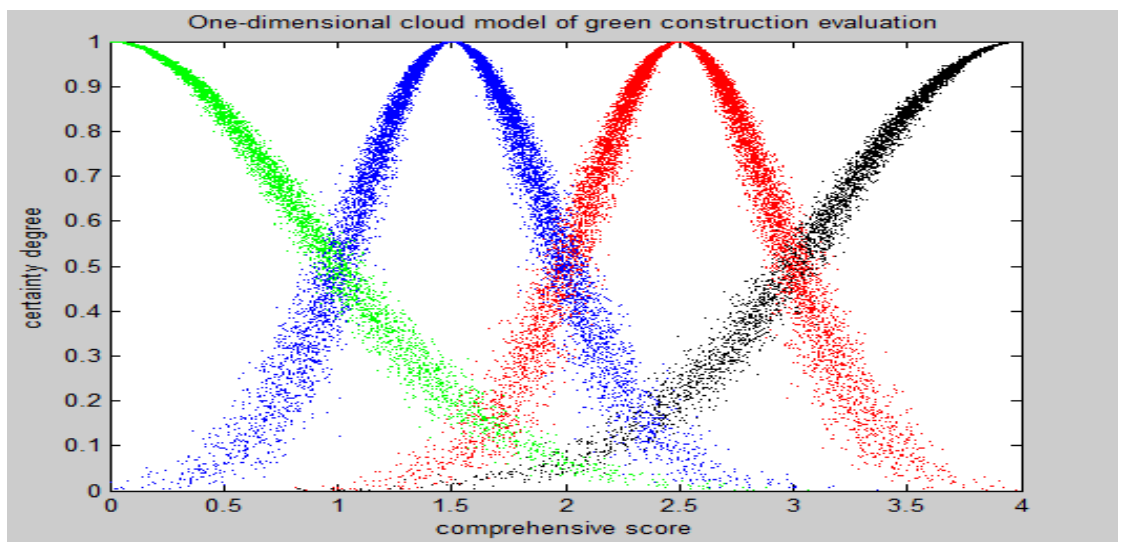

Fig.2 Normal cloud model

In this paper, $\mathrm{N}=1000$, with $\mathrm{X}$ condition cloud generator as the medium,producing membership degree matrix by inputting each object index value and calculating the average of comprehensive evaluation in different membership condition. This example builds on P1 (Table 3). 
Tab. 3 Comprehensive average evaluation value of cloud model

\begin{tabular}{c|cccc}
\hline Coding & ExcellentIV & GoodIII & Qualified II & Unqualified I \\
\hline M1 & 0.0628 & 0.4995 & 0.5001 & 0.0627 \\
M2 & 0.0823 & 0.6420 & 0.3682 & 0.0473 \\
M3 & 0.1700 & 0.9726 & 0.1060 & 0.0186 \\
M4 & 0.0472 & 0.3683 & 0.6419 & 0.0823 \\
M5 & 0.0820 & 0.6413 & 0.3682 & 0.0472 \\
M6 & 0.3101 & 0.8947 & 0.0186 & 0.0064 \\
M7 & 0.0627 & 0.4994 & 0.4992 & 0.0623 \\
L1 & 0.0064 & 0.0187 & 0.8948 & 0.3102 \\
L2 & 0.1060 & 0.7786 & 0.2567 & 0.0352 \\
L3 & 0.0352 & 0.2574 & 0.7785 & 0.1060 \\
L4 & 0.0822 & 0.6414 & 0.3689 & 0.0471 \\
L5 & 0.2574 & 0.9726 & 0.0354 & 0.0093 \\
L6 & 0.0350 & 0.2571 & 0.7786 & 0.1059 \\
S1 & 0.0093 & 0.0353 & 0.9726 & 0.2575 \\
S2 & 0.0064 & 0.0187 & 0.8950 & 0.3101 \\
R1 & 0.0132 & 0.0631 & 1.0000 & 0.2100 \\
R2 & 0.0820 & 0.6421 & 0.3684 & 0.0473 \\
R3 & 0.0350 & 0.2572 & 0.7792 & 0.1062 \\
E1 & 0.0257 & 0.1700 & 0.8947 & 0.1351 \\
E2 & 0.0132 & 0.0627 & 1.0000 & 0.2107
\end{tabular}

According to tab.2 and formula (1) - (5), using entropy method to calculate the weight $\omega$ of each index:

$\omega=\{0.0471,0.0461,0.0467,0.0477,0.0467,0.0454,0.0442,0.0567,0.0456,0.0671$, $0.0471,0.0477,0.0588,0.0492,0.0484,0.0465,0.0480,0.0631,0.0546,0.0434\}$.

Finally, according to the step 6 to calculate fuzzy subset G. On the basis of the maximum membership principle, selecting evaluation rand which corresponding the biggest membership as comprehensive evaluation of the results (Table 4).

Tab. 4 Evaluation results for green construction

\begin{tabular}{c|cccccc}
\hline $\begin{array}{c}\text { Project } \\
\text { label }\end{array}$ & \multicolumn{5}{|c}{ Normal cloud membership } \\
\cline { 2 - 7 } & ExcellentIV & GoodIII & Qualified II & Unqualified I Cloud Evaluation & Fuzzy evaluation \\
\hline P1 & 0.0729 & 0.4189 & 0.5925 & 0.1133 & II & II \\
P2 & 0.2887 & 0.4683 & 0.2764 & 0.0775 & III & III \\
P3 & 0.5455 & 0.4508 & 0.0126 & 0.0034 & IV & III \\
P4 & 0.2989 & 0.5225 & 0.2588 & 0.0364 & III & III \\
\hline
\end{tabular}

As it can be seen from the evaluation results, the green construction evaluation of 4 projects sorting for $\mathrm{P} 3>\mathrm{P} 4=\mathrm{P} 2>\mathrm{P} 1$ by cloud model.Comparing it with results of fuzzy comprehensive evaluation method,it can be show that the results are basically consistent and in line with the actual situation.Cloud model solve the existing problem of the randomness and fuzziness in the evaluation. The evaluation results of cloud model are random that it is one random realization of evaluation, but the result will be in an acceptable range which reflects the uncertainty of evaluation results.

\section{Conclusion}

Based on the existing green construction evaluation index system, a new green construction evaluation system is constructed considering the construction technology management, the construction process of environmental load, energy consumption, resource utilization and economy index,and it introduces cloud model to the field of green construction evaluation and achieves the uncertain transformation between qualitative concept and its quantitative representation.It carries out the green construction evaluation with 4 projects as an case. The results show that the cloud model of entropy can better solve the correlation of uncertainty of randomness and fuzziness. And it is proved that cloud model is reliable and superior on green construction evaluation. 


\section{References}

[1] Rui Pan.Study on Green Construction and Index System of Green Construction Assessment.Proc 17th IEEE Int Conf on Industrial Engineering and Engineering Management(IE\&EM), 1221-1225(2010).

[2] Liu Guiwen, $\mathrm{Xu}$ Pengpeng.The Green Construction Assessment Based on Fuzzy Comprehensive Evaluation[J].Ecological economy(Academic Edition),vol.02:31-33+37(2007).

[3] Li Hui-ling,LI Jun,Zhong Qin.Green Construction Evaluation Based on Grey Clustering Method[J].Journal of Engineering Management,vol.02:18-22(2012).

[4] Li Deyi,Meng Hai jun,Shi Xuemei.Membership clouds and membership cloud generators[J].Journal of Integrative Plant Biology,vol.06:15-20(1995).

[5] Wang GuoYin,Li Deyi,YAO YiYu.Cloud model and granular computing[M].Beijing: Science Press, 2012. 